(C) 2014

\author{
Ляиенко С. В., кандидат технічних наук
}

Полтавська державна аграрна академія

\title{
УДОСКОНАЛЕННЯ ГРАФІКА ПРОВЕДЕННЯ ТА РОЗШИРЕННЯ ПЕРЕЛІКУ НЕОБХІДНИХ ДО ВИКОНАННЯ ОПЕРАЦЙ ТЕХНІЧНИХ ОБСЛУГОВУВАНЬ ЗАСОБІВ МАЛОЇ МЕХАНІЗАЦЇ̈ ЗА РЕЗУЛЬТАТАМИ ЇХ ВИПРОБУВАНЬ НА ПРИСАДИБНИХ ДІЛЯНКАХ
}

\section{Рецензент - кандидат технічних наук В. М. Сакало}

Розглянуто аналіз операчій технічного обслуговування, передбачених до виконання для мотокультиватора WEIMA 900M. Удосконалено графік проведення та розширено перелік необхідних до виконання операчій технічного обслуговування мотокультиватора за результатами його випробувань на присадибних ділянках. Розроблено систему управління експлуатацією мотокультиватора, щуо базується на зборі й використанні бази даних про поломки та несправності й дає можливість попереджувати їх під час проведення технічних обслуговувань, а цее, в свою чергу, дає можливість контролювати технічнии стан мотокультиватора впродовж усього періоду експлуатаціï.

Ключові слова: мотокультиватор, технічне обслуговування, несправність, технічний стан, надійність, експлуатація.

Постановка проблеми. За останні роки суттєво зріс попит на засоби малої механізації, що використовуються на присадибних ділянках Полтавського регіону. Переважна більшість споживачів - це мешканці сільських територій. Придбавши мотокультиватор, споживач зіштовхується 3 інформаційною проблемою переліку операцій технічного обслуговування техніки та періодичністю їх проведення, адже в інструкції заводу-виготовлювача подається мінімальна інформація з цього питання. В цих умовах ускладнюється експлуатація засобів малої механізації, що потребує удосконалення графіка проведення та розширення необхідних до виконання операцій технічного обслуговування 3 метою зменшення витрат на підтримування в працюючому стані мотокультиватора.

Аналіз основних досліджень і публікацій, у яких започатковано розв'язання проблеми. Останнім часом у мережі магазинів суттєво збільшився обсяг різних моделей мотокультиваторів для присадибних ділянок. Виконано огляд основних досліджень і публікацій із даного питання, встановлено, що у роботі [5] представлена класифікація мініагротехнічних засобів (MAT) залежно від маси й потужності двигуна. Найбі- льшим попитом серед споживачів мотокультиваторів (за даними анкетного опитування у Полтавському регіоні) користуються мотокультиватори середнього класу потужністю 5,0-7,0 к. с. і шириною захвату близько $90 \mathrm{~cm}$, розрахованих для обробітку ділянки площею близько 1 га [4]. Аналіз останніх досліджень і публікацій (М. В. Молодик, Гуков Я. С., Моргун А. М., Сiдашенко О. І., Науменко О. А., Козаченко О. В.) показав, що дослідження надійності машин у процесі експлуатації, технічного обслуговування й ремонту пов'язані 3 якісним забезпеченням сервісного обслуговування протягом усього періоду експлуатації [1-3].

За результатами аналізу робіт провідних фахівців можна зробити висновок, що існує значна інформаційна база для розробки системи управління експлуатацією мотокультиватора, що базується на накопиченні й використанні бази даних про поломки та несправності, даючи змогу попереджувати їх під час проведення технічних обслуговувань.

Мета і завдання досліджень. Мета: підвищення ефективності використання мотокультиваторів шляхом розробки комплексу операцій технічного обслуговування, направлених на підтримання в роботоздатному і справному стані його вузлів під час використання за призначенням, а також у зберіганні й транспортуванні.

Основними завданнями досліджень $є$ : проаналізувати операції технічного обслуговування, передбачених до виконання заводом-виготовлювачем для мотокультиватора WEIMA 900M; удосконалити графік проведення технічних обслуговувань даного мотокультиватора; розробити розширений перелік необхідних до виконання операцій технічного обслуговування мотокультиватора за результатами його випробувань на присадибних ділянках.

Матеріали і методи досліджень. Технологія розроблена з використанням основних положень планово-попереджувальної системи технічного обслуговування, що дає можливість попередити 


\section{TEХНIЧНІ НАУКИ}

виникнення несправностей та відмов, зменшити шкідливий вплив старіння, розрегулювань i зношування, зробити роботу мотокультиватора протягом усього періоду експлуатації високопродуктивною й економічною. Обгрунтування додаткових операцій технічного обслуговування мотокультиватора здійснювалося 3 використанням існуючих і нових методів експериментальних досліджень. Використана методика планування багатофакторного експерименту. Результати експериментальних досліджень оброблено 3 використанням положень математичної статистики. Агротехнічна й енергетична оцінки проводилися з використанням галузевих стандартів.

Результати досліджень. За результатами проведених у 2013-2014 pр. досліджень на присадибній ділянці мотокультиватора WEIMA 900M встановлено, що необхідно не лише забезпечувати технічний стан мотокультиватора у відповідності до вимог нормативно-технічної документації, але й використовувати додатковий комплекс заходів і засобів, які створюють умови для довготривалішого його терміну експлуатації. Для цього необхідна більш повна інформація про відмови в роботі мотокультиватора, його агрегатах і системах.

Така інформація була зібрана за рік інтенсивної експлуатації мотокультиватора WEIMA 900М на присадибній ділянці за різних режимів його експлуатації, а результати узагальнені й представлені у вигляді розширеної таблиці, обов'язкових до виконання операцій технічного обслуговування 3 удосконаленим графіком їх проведення.

\section{Перелік обов'язкових до виконання операцій технічного обслуговування мотокультиватора та графік їх проведення}

\begin{tabular}{|c|c|}
\hline Операція технічного обслуговування & Причини, зауваження \\
\hline 1 & 2 \\
\hline \multicolumn{2}{|c|}{$\begin{array}{c}\text { ТЕХНІЧНЕ ОБСЛУГОВУВАННЯ МОТОКУЛЬТИВАТОРА } \\
\text { У ХОДІ ЕКСПЛУАТАЦІЙНОЇ ОБКАТКИ }\end{array}$} \\
\hline \multicolumn{2}{|c|}{ 1. Підготовка мотокультиватора до обкатки } \\
\hline 1. Підготовте мотокультиватор до обкатки & 1. Тривалість операцій - 20 хв. \\
\hline $\begin{array}{l}\text { 1.1. Огляньте та очистіть від пилу, бруду й консе- } \\
\text { рваційного мастила мотокультиватор. }\end{array}$ & $\begin{array}{l}\text { 1.1. Поверхні деталей можуть містити консерва- } \\
\text { ційні матеріали. }\end{array}$ \\
\hline $\begin{array}{l}\text { 1.2. Перевірте рівні мастил у картері двигуна та } \\
\text { картері трансмісії, за необхідності - долийте. }\end{array}$ & $\begin{array}{l}\text { 1.2. Мастило може бути відсутнім, а його рівень } \\
\text { нижчим номінально допустимого. }\end{array}$ \\
\hline $\begin{array}{l}\text { 1.3. Виконайте змащування окремих вузлів відпо- } \\
\text { відно до таблиці мащення. }\end{array}$ & 1.3. Змащування вузлів може бути відсутнім. \\
\hline $\begin{array}{l}\text { 1.4. Перевірте і в разі необхідності підтягніть } \\
\text { різьбові та інші з'єднання мотокультиватора }\end{array}$ & $\begin{array}{l}\text { 1.4. Поспіх у ході збирання мотокультиватора } \\
\text { призводить до неповного затягування різьбових } \\
\text { 3'єднань. }\end{array}$ \\
\hline $\begin{array}{l}\text { 1.5. Перевірте і за необхідності відрегулюйте на- } \\
\text { тяг пасів приводу трансмісії, механізму керуван- } \\
\text { ня дросельною заслінкою та зчеплення, тиск по- } \\
\text { вітря в шинах коліс. }\end{array}$ & $\begin{array}{l}\text { 1.5. Під час короткотривалого випробування на } \\
\text { заводі можливі розрегулювання механізмів мото- } \\
\text { культиватора. }\end{array}$ \\
\hline $\begin{array}{l}\text { 1.6. Заправте паливом систему живлення двигуна, } \\
\text { перевірте їі на герметичність. }\end{array}$ & $\begin{array}{l}\text { 1.6 Можливі підтікання через заливну горловину } \\
\text { бака. }\end{array}$ \\
\hline \multicolumn{2}{|c|}{ 2. Обкатка двигуна на холостому режимі } \\
\hline $\begin{array}{l}\text { 2. Виконайте обкатку двигуна на холостому ре- } \\
\text { жимі за частоти обертання колінчастого вала } \\
900-1500,2500-3000 \text { об./хв. }\end{array}$ & $\begin{array}{l}\text { 2. Тривалість операції - } 10 \text { хв. Перевіряйте рівень } \\
\text { масла в піддоні картера двигуна і за необхідності } \\
\text { виконайте дозаправку до заданого рівня. }\end{array}$ \\
\hline \multicolumn{2}{|c|}{ 3. Обкатка мотокультиватора на холостому ходу } \\
\hline $\begin{array}{l}\text { 3. Виконайте обкатку мотокультиватора на холо- } \\
\text { стому ходу за наступним режимом: }\end{array}$ & $\begin{array}{l}\text { 3. Тривалість операції - } 40 \text { хв. Перевіряйте зов- } \\
\text { нішнім оглядом відсутність підтікання палива, } \\
\text { масла і в разі потреби усувайте виявлені підті- } \\
\text { кання }\end{array}$ \\
\hline $\begin{array}{l}\text { 3.1. Переміщення на першій передачі переднього } \\
\text { ходу по прямій; }\end{array}$ & 3.1. Тривалість операції - 10 хв. \\
\hline $\begin{array}{l}\text { 3.2. Переміщення на другій передачі переднього } \\
\text { ходу по прямій; }\end{array}$ & 3.2. Тривалість операції- 10 хв. \\
\hline
\end{tabular}




\begin{tabular}{|c|c|}
\hline & Продовження таблищі \\
\hline 1 & 2 \\
\hline $\begin{array}{l}\text { 3.3. Переміщення на передачі заднього ходу по } \\
\text { прямій; }\end{array}$ & 3.3. Тривалість операції - 10 хв. \\
\hline $\begin{array}{l}\text { 3.4. Переміщення на першій та другій передачах } \\
\text { переднього ходу, замінюючи рух по прямій на } \\
\text { рух із крутими поворотами вліво і вправо. }\end{array}$ & 3.4. Тривалість операції- 10 хв. \\
\hline \multicolumn{2}{|c|}{ 4. Обкатка мотокультиватора під навантаженням } \\
\hline $\begin{array}{l}\text { 4. Виконайте обкатку мотокультиватора під } \\
\text { навантаженням. }\end{array}$ & $\begin{array}{l}\text { 4. Перші } 20 \text { год. експлуатації. Проводьте на різ- } \\
\text { них передачах залежно від величини навантажен- } \\
\text { ня на кожному етапі обкатки. За необхідності ви- } \\
\text { конайте додаткову перевірку вільного ходу реме- } \\
\text { нів приводу трансмісії. }\end{array}$ \\
\hline $\begin{array}{l}\text { 4.1. На першому етапі обкатки навантаження до- } \\
\text { водьте до 20-25 \% від номінального. }\end{array}$ & 4.1. Тривалість операції - 3 год. \\
\hline $\begin{array}{l}\text { 4.2. На другому етапі обкатки навантаження до- } \\
\text { водьте до 50-60 \% від номінального. }\end{array}$ & 4.2. Тривалість операції - 7 год. \\
\hline $\begin{array}{l}\text { 4.3. На третьому етапі обкатки навантаження до- } \\
\text { водьте до } 75-80 \% \text { від номінального. }\end{array}$ & ціï - 10 год. \\
\hline \multicolumn{2}{|c|}{ 5. Огляд та обслуговування після закінчення експлуатаційної обкатки } \\
\hline $\begin{array}{l}\text { 5. Виконайте огляд та обслуговування після за- } \\
\text { кінчення перших } 20 \text { год. експлуатаційної обкатки. }\end{array}$ & 5. Тривалість операції - 60 хв. \\
\hline 5.1. Огляньте та очистіть мотокультиватор. & $\begin{array}{l}\text { 5.1. Очищення слід виконувати стисненим повіт- } \\
\text { рям. }\end{array}$ \\
\hline $\begin{array}{l}\text { 5.2. Перевірте і в разі необхідності відрегулюйте } \\
\text { вільний хід ременів приводних пасів трансмісії, } \\
\text { тиск повітря в шинах коліс. }\end{array}$ & $\begin{array}{l}5.2 \text { Вільний хід ременів повинен становити 60-65 мм } \\
\text { у місці натяжного ролика з увімкненим зчеплен- } \\
\text { ням. }\end{array}$ \\
\hline $\begin{array}{l}\text { 5.3. Перевірте зазори газорозподільного механіз- } \\
\text { му двигуна. }\end{array}$ & $\begin{array}{l}\text { 5.3. Зазори газорозподільного механізму необхід- } \\
\text { но перевіряти на прогрітому двигуні. }\end{array}$ \\
\hline $\begin{array}{l}\text { 5.4. Виконайте технічне обслуговування повітря- } \\
\text { ного фільтра, виконуючи операції за наступною } \\
\text { послідовністю: }\end{array}$ & $\begin{array}{l}\text { 5.4. Усі елементи повітряного фільтра ретельно } \\
\text { очистити від пилу та бруду перед його демонта- } \\
\text { жем. }\end{array}$ \\
\hline $\begin{array}{l}\text { 5.4.1. Відкрутіть баранцеву гайку кріплення кри- } \\
\text { шки повітряного фільтра. } \\
\text { 5.4.2. Зніміть кришку фільтра. }\end{array}$ & $\begin{array}{l}\text { Слід пам'ятати, що викручувати пористий еле- } \\
\text { мент, виготовлений із поролону, не можна, щоб } \\
\text { запобігти його пошкодженню. }\end{array}$ \\
\hline $\begin{array}{l}\text { 5.4.3. Зніміть пористий елемент, виготовлений із } \\
\text { поролону. } \\
\text { 5.4.4. Вимийте пористий елемент у бензині чи } \\
\text { керосині. } \\
\text { 5.4.5. Просочіть пористий елемент у маслі } \\
\text { М12ГИ, залишки масла акуратно відтисніть. } \\
\text { 5.4.6. Зберіть фільтр у зворотньому порядку. }\end{array}$ & $\begin{array}{l}\text { На дно корпусу фільтра влити } 100-150 \text { мл масла } \\
\text { М12ГИ. }\end{array}$ \\
\hline $\begin{array}{l}\text { 5.5. Підтягніть зовнішні кріплення складових ча- } \\
\text { стин (у тому числі кріплення головки двигуна). }\end{array}$ & $\begin{array}{l}\text { 5.5. Вплив вібрації на з’єднувальні елементи мо- } \\
\text { же призвести до їх ослаблення. }\end{array}$ \\
\hline $\begin{array}{l}\text { 5.6. Очистіть паливний фільтр, виконуючи опера- } \\
\text { ції за наступною послідовністю: }\end{array}$ & $\begin{array}{l}\text { 5.6. Усі елементи паливного фільтра ретельно очис- } \\
\text { тити від пилу та бруду перед його демонтажем. }\end{array}$ \\
\hline $\begin{array}{l}\text { 5.6.1. Перемістіть паливний краник у положення «за- } \\
\text { крито». } \\
\text { 5.6.2. Відкрутіть гайку паливного фільтра і маслоут- } \\
\text { римуюче кільце. } \\
\text { 5.6.3. Промийте деталі в розчиннику, ретельно очис- } \\
\text { тивши їх. } \\
\text { 5.6.4. Зберіть паливний фільтр у зворотньому поряд- } \\
\text { ку. }\end{array}$ & $\begin{array}{l}\text { Бензин - самозаймиста та вибухонебезпечна ре- } \\
\text { човина. Не паліть і переконайтеся, що поряд iз } \\
\text { паливом немає вогню чи іскри. }\end{array}$ \\
\hline
\end{tabular}


TEХНIЧНI НАУКИ

\begin{tabular}{|c|c|}
\hline & Продовження таблиц \\
\hline 1 & T \\
\hline 5.7. Замініть масло в двигуні. & $\begin{array}{l}\text { 5.7. Рекомендується використовувати моторне } \\
\text { масло типу SAE } 10 \mathrm{~W}-30 \text { у кількості } 450 \text { мл. }\end{array}$ \\
\hline 5.8. Замініть масло в трансмісії. & $\begin{array}{l}\text { 5.8. Рекомендується використовувати трансмісій- } \\
\text { не масло типу ТАП-15В у кількості } 750 \text { мл. }\end{array}$ \\
\hline $\begin{array}{l}\text { 5.9. Огляньте і прослухайте в роботі складові } \\
\text { частини мотокультиватора. }\end{array}$ & 5.9. Виявлені дефекти та недоліки усуньте. \\
\hline \multicolumn{2}{|c|}{$\begin{array}{l}\text { 6. Щоденне технічне обслуговування } \\
\text { (після кожних } 8 \text { годин експлуатації) }\end{array}$} \\
\hline 6.1. Очистіть мотокультиватор від пилу. & $\begin{array}{l}\text { 6.1. Пил може погіршувати роботу окремих вуз- } \\
\text { лів. Особливо чутливим до пилу є з’єднувач ре- } \\
\text { гулятора. }\end{array}$ \\
\hline $\begin{array}{l}6.2 \text { Перевірте підтікання палива. За необхідності } \\
\text { підтягніть або замініть деталі. }\end{array}$ & 6.2. Підтікання неекономічні та небезпечні. \\
\hline $\begin{array}{l}6.3 \text { Переконайтеся, що всі деталі міцно закріпле- } \\
\text { ні. За необхідності підтягніть. }\end{array}$ & $\begin{array}{l}\text { 6.3. Незакріплені деталі можуть викликати вібра- } \\
\text { цію і створити аварійну ситуацію. }\end{array}$ \\
\hline $\begin{array}{l}6.4 \text { Перевірте рівень масла у двигуні та трансмісії і за } \\
\text { необхідності долийте до максимальної позначки. }\end{array}$ & $\begin{array}{l}\text { 6.4. Експлуатація двигуна та мотокультиватора з не- } \\
\text { достатньою кількістю масла може призвести до сер- } \\
\text { йозних наслідків, включаючи заклинювання двигуна } \\
\text { або вихід із ладу трансмісії мотокультиватора. }\end{array}$ \\
\hline $\begin{array}{l}6.5 \text { Переконайтеся у чистоті фільтруючого елеме- } \\
\text { нту повітряного фільтра. Занеобхідності вико- } \\
\text { найте його очищення (див п. 5.4) або заміну. }\end{array}$ & $\begin{array}{l}\text { 6.5. Забруднення повітряного фільтра може при- } \\
\text { 3вести до втрати потужності та порушити норма- } \\
\text { льну роботу двигуна. }\end{array}$ \\
\hline \multicolumn{2}{|c|}{ 7. Огляд і технічне обслуговування після перших 100 годин експлуатації (кожні 10 днів) } \\
\hline 7.1. Замініть моторне масло. & $\begin{array}{l}\text { 7.1. Рекомендується використовувати моторне } \\
\text { масло типу SAE } 10 \mathrm{~W}-30 \text { у кількості } 550 \text { мл. }\end{array}$ \\
\hline 7.2. Очистіть повітряний фільтр (див. п. 5.4) & $\begin{array}{l}\text { 7.2. Забруднення повітряного фільтра може по- } \\
\text { рушити нормальну роботу двигуна. }\end{array}$ \\
\hline
\end{tabular}

7.3. Перевірте свічку запалення. Очистіть забруд- 7.3. Несправна свічка запалення може знизити нення бензином чи наждачним папером. Перевір- вихідну потужність, погіршити пускові характете зазор свічки запалення і за необхідності відре- ристики. Зазор свічки запалення повинен станогулюйте його. вити $0,7-0,8$ мм.

7.4 Перевірте ущільнювальне кільце паливного 7.4. За рахунок послаблення ущільнювального кільця фільтра і за необхідності замініть його. Очистіть може відбуватися протікання палива, що $\epsilon$ безпосепаливний фільтр, виконуючи операції за п. 5.6.

7.5. Перевірте і за необхідності відрегулюйте тро- 7.5. Вільний хід на кінці ручки повинен становисик зчеплення. ти 3-8 мм.

7.6. Перевірте і в разі необхідності відрегулюйте 7.6 Вільний хід пасів повинен становити 60-65 мм у вільний хід приводних пасів трансмісії ням.

7.7. Нанесіть захисне покриття на пошкоджені 7.7 Пошкоджені ділянки лакофарбового покриття ділянки лакофарбової поверхні складових частин можуть перебувати під впливом корозії, що примотокультиватора. зводить до руйнування корпусних деталей.

8. Огляд та обслуговування кожні 100-200 годин експлуатації (кожен місяць)

\begin{tabular}{|l|l|}
\hline 8.1. Очистіть паливний бак і сітчастий фільтр & 8.1. Забруднене паливо може порушити нормаль-
\end{tabular} ну роботу двигуна.

8.2. Замініть фільтруючий елемент повітряного 8.2. Забруднення повітряного фільтра може пофільтра. рушити нормальну роботу двигуна.

9. Огляд та обслуговування кожні 300 годин експлуатації (кожен квартал)

9.1. Перевірте і за необхідності відрегулюйте 9.1. Розрегульовані зазори клапанів можуть призазори впускного і випускного клапанів. звести до зниження вихідної потужності двигуна й порушити його нормальну роботу. 


\begin{tabular}{|c|c|}
\hline & Продовження таблиц \\
\hline 1 & 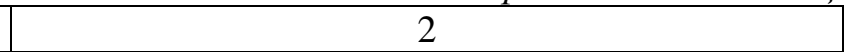 \\
\hline $\begin{array}{l}\text { 9.2. Перевірте і за необхідності відрегулюйте на- } \\
\text { тяг тросика дросельної заслінки. }\end{array}$ & $\begin{array}{l}\text { 9.2. Вільний хід на кінці ручки повинен станови- } \\
\text { ти 5-10 мм. }\end{array}$ \\
\hline \multicolumn{2}{|c|}{ 10. Огляд та обслуговування кожні 500-600 годин експлуатації (кожні 6 місяців) } \\
\hline $\begin{array}{l}\text { 10.1. Розберіть і проведіть очищення карбюрато- } \\
\text { ра. }\end{array}$ & $\begin{array}{l}\text { 10.1. Несправний карбюратор може порушити } \\
\text { нормальну роботу двигуна. }\end{array}$ \\
\hline 10.2. Замініть свічку запалювання. & $\begin{array}{l}\text { 10.2. Рекомендовано використовувати свічки за- } \\
\text { палювання: BPR5ES (NGK), W16EPR-V } \\
\begin{array}{ll}\text { (NIPPONDENSO) } & \end{array}\end{array}$ \\
\hline \multicolumn{2}{|c|}{ 11. Огляд та обслуговування кожні 1000 годин експлуатації } \\
\hline $\begin{array}{l}\text { 11.1. Переберіть двигун. Проведіть очищення де- } \\
\text { талей, відремонтуйте несправні деталі або замі- } \\
\text { ніть їх. }\end{array}$ & $\begin{array}{l}\text { 11.1. Забруднені, роз регульовані та зношені де- } \\
\text { талі можуть знизити вихідну потужність і пору- } \\
\text { шити нормальну роботу двигуна. }\end{array}$ \\
\hline 11.2. Виконайте заміну поршневих кілець. & $\begin{array}{l}\text { 11.2. Дефекти поршневих кілець можуть знизити } \\
\text { вихідну потужність і порушити нормальну робо- } \\
\text { ту двигуна. }\end{array}$ \\
\hline 11.3. Замініть паливний шлаң & $\begin{array}{l}\text { 11.3. Для запобігання протікання палива та інших } \\
\text { похідних небезпечних наслідків. }\end{array}$ \\
\hline
\end{tabular}

Як видно 3 даних таблиці, досвід польових випробувань мотокультиватора WEIMA 900М на присадибній ділянці за різних режимів його експлуатації дав можливість розробити розширений перелік необхідних до виконання операцій технічного обслуговування мотокультиватора та удосконалити графік їх проведення. На основі зібраної та використаної бази даних про поломки й несправності (за період експлуатаціі) запропоновано використовувати розроблену систему управління експлуатацією мотокультиватора, що дає змогу, використовуючи таблицю 1 , попереджувати несправності під час проведення технічних обслуговувань, а це дає можливість контролювати технічний стан мотокультиватора протягом усього періоду експлуатації за умови чіткої фіксації наробітку в годинах.

Висновки: 1. На основі аналізу існуючої таблиці проведення технічних обслуговувань мото-

\section{БІБЛІОГРАФІЯ}

1. Козаченко О. В. Проблеми та перспективи розвитку технічного сервісу машин АПК [Текст] / О. В. Козаченко // Вісник ХНТУСГ ім. П. Василенка. - Вип. 145. - Харків, 2014. - С. 3-7.

2. Концепція організації технічного сервісу АПК Харківського регіону // О. І. Сідашенко, О. А. Науменко, О. В. Козаченко [та ін.]. ХДТУСГ. - Харків, 2000. - 15 с.

3. Концепція перспективного розвитку технічного сервісу АПК України / Я.С.Гуков, М. В. Молодик, А. М. Моргун [та ін.]. - Глеваха: культиватора WEIMA 900M (наведеної у заводській інструкції з експлуатації й технічному обслуговуванні) встановлено, що для підвищення ефективності використання мотокультиваторів необхідно розширити перелік необхідних до виконання операцій технічного обслуговування та удосконалити графік їх проведення.

2. Запропонований удосконалений графік проведення технічних обслуговувань мотокультиватора дав можливість підвищити період безвідмовної його роботи до $40 \%$ (за результатами його випробувань на присадибних ділянках) порівняно з існуючим графіком.

3. Розроблений розширений перелік необхідних до виконання операцій технічного обслуговування мотокультиватора не потребує значних капіталовкладень, а вчасне їх виконання дає можливість зменшити витрати на ремонт і технічне обслуговування на $15 \%$.

ННЦ ІМЕСГ, 2004. - 59 с.

4. Ляшенко С. В. Удосконалення малої механізації в технології вирощування картоплі на присадибних ділянках [Текст] / С.В. Ляшенко, В. В. Падалка // Вісник ПДАА. - № 1, 2013. C. 151-154.

5. Молодик М. В. Оцінювання надійності машин при експлуатації, технічному обслуговуванні і ремонті / Міжвід. темат. наук. зб. «Механізація та електрифікація сільського господарства». Вип. 92. - Глеваха, 2008. - С. 381-390. 